\title{
International Journal of Health Services Research and Policy
}

www.dergipark.org.tr/ijhsrp

IJHSRP

e-ISSN: 2602-3482

Research Article

\section{NURSES' PERCEIVED AND ACTUAL PREPAREDNESS FOR DISASTERS}

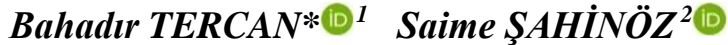 \\ ${ }^{1}$ Erzincan Binali Yıldırım University, Health Services Vocational School, First and Emergency Department, \\ Erzincan, Turkey \\ ${ }^{2}$ Ordu University, Faculty of Medicine, Department of Public Health, Ordu, Turkey \\ *Corresponding author; bhdr_24@ hotmail.com
}

\begin{abstract}
This study aimed to determine the preparedness and preparedness perception of nurses against disasters. This study was carried out in the hospitals of Gümüşhane Provincial Health Directorate between 01/11/2014 - 24/11/2015 as a cross-sectional study. The universe of the study consisted of 226 nurses working in the clinics of Gümüşhane Public Hospitals Association affiliated hospitals. The entire universe was included without using any sampling method. The study was completed with 171 nurses and response rate was 75,67\%. "Personal Information Form and "Perception of Disaster Preparedness Scale in Nurses" were used to collect data. Data were collected between December 2014 - January 2015. Nurses had moderate perception according to the perception of disaster preparedness scale. It was found that those who had the highest perception in the disaster response phase were the nurses working in the intensive care + operating room. Besides, preparedness perceptions of nurses participating in disaster drills were found to be higher than non-participants. It was concluded that the nurses' perceptions of disaster preparedness were moderate. It is recommended that nurses' perceptions of preparedness against disasters must be kept high by providing adequate and regular training and drills on disaster preparedness.
\end{abstract}

Keywords: Disaster, Disaster Management, Nursing, Perception, Preparedness

Received: July 6, $2020 \quad$ Accepted: May 20, 2021

\section{Introduction}

Natural, human or technological disasters that cause loss of life and property occur almost every day in the world [1]. In our country, it is known that natural disasters such as earthquakes, floods, and landslides are frequent and especially earthquakes cause loss of life and property [2]. Due to the insufficient preparedness for disasters in the Marmara earthquake which is a turning point for our country in terms of disaster management, the loss of life and property has reached very serious dimensions, which has increased the awareness of the state and society in particular. With the establishment of the Disaster and Emergency Management Presidency (AFAD) as of 2009, significant developments have been experienced in disaster management and preparedness for disasters has shown a reduction of the loss of life and property after disasters [3].

Successful disaster management depends on effective disaster preparedness [4]. Disaster preparation is a process in which sustained and sustainable situations such as planning, training, drilling, setting up early warning systems, raising public awareness about disasters, and periodically reweaving emergency stock supplies are carried out before disasters occur $[5,6]$. 
Nurses, which constitute the largest professional group in health services, are one of the most important resources of the society with their disaster preparedness, their effective role in participating in disaster management, and the care they will provide to maintain the health and welfare of the society [7-9]. Many studies in the international literature show that nurses are aware of their role in disaster management [10-14]. When we look at our country, it is seen that the terms "Nurse" and "Disaster" are used together in a few recent studies [15,16].

Disasters in the 21 st century have led to a significant change in the role of professional nursing in disaster management [17-19]. Nurses have to follow current education and technology to provide quality health care to individuals, families, and communities during and after the disaster [20]. If nurses and other health professionals have sufficient knowledge and equipment to prepare for disasters; much faster planning can be done in the crisis period and health services can be provided efficiently. In light of this information, our research was carried out to determine the preparedness of nurses against disasters and to measure their perceptions of preparedness before, during, and after the disaster.

\section{Material and Methods}

\subsection{Aim and Type of Research}

This cross-sectional study was conducted to determine the preparedness of nurses against disasters in disaster management and to measure their pre-disaster, disaster sequence, and post-disaster preparedness perceptions.

\subsection{Place and Time of Study}

This study was carried out in Gümüşhane State Hospital, Kelkit State Hospital, and Şiran State Hospital of Gümüşhane Provincial Health Directorate between 01/11/2014 - 24/11/2015.

\subsection{Universe and Sample of the Study}

The universe of the study consisted of nurses working in Gümüşhane State Hospital, Kelkit State Hospital, and Şiran State Hospital of Gümüşhane Provincial Health Directorate. 154 nurses work in Gümüşhane State Hospital, 58 nurses in Kelkit State Hospital, and 14 nurses in Şiran State Hospital. It was aimed to reach the whole universe and no sampling method was used. The study was completed with 171 nurses (response rate: $75.67 \%$ ). A total of 55 nurses who were on leave (annual and maternity leave) and those who had health reports and those who refused to participate in the study were excluded from the study.

\subsection{Data Collection Tools}

"Personal Information Form" was used to get demographic information about participants. "Disaster Preparedness Perception Scale in Nurses" developed by Özcan and Erol in 2015 was used to collect data [21].

\subsubsection{Personal Information Form and Disaster Preparedness Perception Scale in Nurses}

The first part of this form, which was developed by the researcher in the light of literature information, consisted of 18 questions consisting of the descriptive characteristics of the nurses (age, gender, education level, questions related to disaster preparedness). Disaster Preparedness Perception Scale in Nurses (DPPSN) consists of 20 questions to measure nurses' perceptions of disaster preparedness. The scale was categorized under three headings as the preparation stage (questions 1-6), intervention stage (questions 7-15), and post-disaster stage (questions 16-20). The items of the scale are arranged in a 5-point Likert type (1-Strongly disagree, 2- Disagree, 3-Partly agree, 4-Agree, 5-Strongly 
agree) scale, and the perception of disaster preparedness increases as the score obtained from the scale increases. In the study of Özcan and Erol (2013) the Cronbach $\alpha$ values of the scale for 3 dimensions were respectively determined as $0.87,0.88$ and 0.87 . In this study; Cronbach $\alpha$ values for the 3 dimensions were found to be $0.90,0.84$, and 0.82 respectively [21].

\subsection{Data Collection}

Data were collected between December 2014 - January 2015. "Personal Information Form" and "Disaster Preparedness Perception Scale in Nurses" were used in the data collection. The data were collected by applying the questionnaire by face to face interview technique with the nurses who accepted to participate in the research on the days when the researcher was available (Monday, Wednesday, Friday). The average duration of a questionnaire was 5 minutes.

\subsection{Ethical Principles of the Study}

Before starting the research; Written permission was obtained from Gümüşhane Provincial Health Directorate (Date: 30/09/2014, Number: 6190) and Erzincan Binali Y1ldırım University Ethics Committee (Date: 19/01/2015, Number: 01/09). In addition, all nurses were informed about the research, and volunteer information form was read and those who voluntarily agreed to participate in the study were included.

\subsection{Limitations and Generalizability of the Study}

Only nurses working in Gümüşhane State Hospital, Kelkit State Hospital, and Siran State Hospital clinics of Gümüşhane Provincial Health Directorate and accepted to participate in the study were included in the study. No sampling method was used because it was aimed to reach the whole universe. Therefore, the results can be generalized to the universe.

\subsection{Data Analysis}

In the analysis of the data, SPSS (Statistical Package for Social Sciences) 23.0 statistical program was used. In the analysis of the data, number, percentage, arithmetic mean, standard deviation, and chisquare test were used to evaluate the descriptive characteristics of nurses. Besides, Student's t-test, Oneway Anova and Kruskal-Wallis test were used to evaluate the relationship between the descriptive characteristics and the disaster preparedness perception scale in nurses.

\section{Results}

Nurses participating in the study; $69.9 \%$ were employed in Gümüşhane State Hospital and $36.3 \%$ worked in internal clinics, $80.1 \%$ were women, $63.7 \%$ were married, $39.2 \%$ were university graduates, $29.8 \%$ were in the $24-28$ age range and $53.2 \%$ had a working period of fewer than 5 years (Table 1 ). 
Table 1. Distribution of the identifying characteristics of nurses $(n=171)$

\begin{tabular}{lcc}
\hline Identifying Characteristics & $\mathbf{N}$ & $\mathbf{\%}$ \\
\hline Which Hospital They Work & 119 & 69.6 \\
Gümüshane State Hospital & 37 & 21.6 \\
Kelkit State Hospital & 15 & 8.8 \\
Siran State Hospital & & \\
\hline Which Clinics They Worked & 62 & 36.3 \\
Internal Clinic & 30 & 17.5 \\
Surgical Clinic & 21 & 12.3 \\
Emergency Clinic & 36 & 21.1 \\
Intensive Care + Operating Room & 7 & 4.1 \\
Pediatric Clinics & 15 & 8.8 \\
Obstetrics and Gynecology+Delivery Room & & \\
\hline Gender & 137 & 80.1 \\
Female & 34 & 19.9 \\
Male & & \\
\hline Marital status & 109 & 63.7 \\
Married & 62 & 36.3 \\
Single & & \\
\hline Educational level & 57 & 33.3 \\
High School & 43 & 25.1 \\
Vocational School & 67 & 39.2 \\
University Graduate & 4 & 2.3 \\
Master's Degree & & \\
\hline Age & 44 & 25.7 \\
23 and under & 51 & 29.8 \\
29-28 & 22 & 12.9 \\
34-38 & 39 & 22.8 \\
39 and above & 15 & 8.8 \\
\hline Working Time & & \\
Less than 5 years 9 year & 91 & 53.2 \\
10 years and over & 29 & 17.0 \\
Total & 51 & 29.8 \\
\hline & 171 & 100.0 \\
\hline
\end{tabular}

The nurses participating in the study; $67.3 \%$ of them have received disaster-oriented training during their nursing education, $67.8 \%$ have never been exposed to disaster before, $55.6 \%$ have participated in disaster-related drills, $68.4 \%$ are aware of a disaster plan of the hospital they work for and $56.7 \%$ of them were partially prepared for disaster. In addition, of these nurses; $49.7 \%$ participated in the fire drill, $88.9 \%$ thought that the nurse had a role in the post-disaster period, $86 \%$ thought that the nurse had a caring role in the event of a disaster, $99.4 \%$ describe the concept of disaster as natural disasters such as earthquakes, landslides, and landslip and it was determined that $50.5 \%$ of the nurses who were aware of the disaster plan belonging to the hospital they worked had read the plan (Table 2). 
Table 2. Disaster information status of nurses $(n=171)$

\begin{tabular}{lcc}
\hline Disaster Information & $\mathbf{N}$ & $\%$ \\
\hline Education Status & & \\
Trained & 115 & 67.3 \\
Untrained & 56 & 32.7 \\
\hline Did You Experience Disaster? & 55 & 32.2 \\
Yes & 116 & 67.8 \\
No & & \\
\hline Participation in Disaster Drills & 95 & 55.6 \\
Participated & 76 & 44.4 \\
Not participated & & \\
\hline Awareness of Disaster Plan & 117 & 68.4 \\
Yes & 3 & 1.8 \\
No & 51 & 29.8 \\
\hline do not know & & \\
\hline Disaster Preparedness Status & 33 & 19.3 \\
Ready & 41 & 24.0 \\
Not Ready & 97 & 56.7 \\
Partially Ready & 171 & 100.0 \\
\hline Potal & & \\
Firticipated Drills* & 85 & 49.7 \\
Earthquake & 46 & 26.9 \\
\hline The Roles of Nurses in Disasters* & & \\
Pre-Disaster Period & 99 & 57.9 \\
Disaster Period & 151 & 88.3 \\
Post-Disaster Period & 152 & 88.9 \\
\hline Roles* & & \\
Consultant & 103 & 60.2 \\
Caregiver & 147 & 86.0 \\
Trainer & 98 & 57.3 \\
Manager & 107 & 62.6 \\
\hline Disaster Definition * & 72 & 42.1 \\
\hline Natural disasters such as earthquakes, landslides, and landslips & & \\
influenza & 170 & 99.4 \\
Terrorist acts with biological, chemical or explosive agents & 119 & 69.6 \\
Human losses due to collapse in coal and gold mines & 135 & 78.9 \\
All & 146 & 85.4 \\
\hline Disaster Plan Reading Status ** & 113 & 66.1 \\
Read & & \\
Not read & 58 & 50.5 \\
\hline Movian & & \\
\hline & & \\
\hline
\end{tabular}

* More than one answer.

** Percentage is taken from those who say there is a disaster plan.

The mean scores of the DPPSN of the nurses included in the study were $3.68 \pm 0.53$ for the total scale score, $4.19 \pm 0.75$ for the preparatory stage, $3.40 \pm 0.68$ for the intervention stage and $3.58 \pm 0.72$ for the post-disaster stage (Table 3 ). 
Table 3. Distribution of DPPSN and Subdimension Scores $(n=171)$

\begin{tabular}{lccc}
\hline DPPSN and Subdimensions & Mean \pm Sd & Min. & Max. \\
\hline Total Scale & $3.68 \pm 0.53$ & 1.0 & 5.0 \\
Preparatory Phase & $4.19 \pm 0.75$ & 1.0 & 5.0 \\
Intervention Phase & $3.40 \pm 0.68$ & 1.0 & 5.0 \\
Post-Disaster Phase & $3.58 \pm 0.72$ & 1.0 & 5.0 \\
\hline
\end{tabular}

As is seen in Table 4, there were statistically significant differences between some characteristics of the participants and the mean scores of DPPSN and sub-dimensions in terms of participation in the disaster drills $(\mathrm{t}=2.67, \mathrm{p}<0.01)$ and the clinic nurses worked $(\mathrm{KW}=12.84, \mathrm{p}<0.05)$.

Table 4. Distribution of the mean scores of DPPSN and subgroups according to some characteristics of the participants $(n=171)$

\begin{tabular}{|c|c|c|c|c|c|}
\hline Some Characteristics & DPPSN & $\begin{array}{c}\text { Preparatory } \\
\text { Phase }\end{array}$ & $\begin{array}{c}\text { Intervention } \\
\text { Phase }\end{array}$ & $\begin{array}{c}\text { Post- } \\
\text { Disaster } \\
\text { Phase }\end{array}$ & $\begin{array}{c}\text { Statistical } \\
\text { Analysis }\end{array}$ \\
\hline \multicolumn{6}{|l|}{ Gender } \\
\hline Female & $3.69 \pm 0.52$ & $4.22 \pm 0.69$ & $3.38 \pm 0.68$ & $3.59 \pm 0.71$ & \multirow[b]{2}{*}{$\mathrm{t}=0.23$} \\
\hline Male & $\begin{array}{c}3.66 \pm 0.60 \\
\mathrm{p}=0.81\end{array}$ & $\begin{array}{c}4.06 \pm 0.94 \\
p=0.27\end{array}$ & $\begin{array}{c}3.47 \pm 0.71 \\
\mathrm{p}=0.48\end{array}$ & $\begin{array}{c}3.52 \pm 0.78 \\
p=0.59\end{array}$ & \\
\hline \multicolumn{6}{|l|}{ Clinic } \\
\hline Internal Clinic & $3.67 \pm 0.54$ & $4.26 \pm 0.66$ & $3.34 \pm 0.69$ & $3.54 \pm 0.81$ & \multirow{7}{*}{$\mathrm{KW}=9.65$} \\
\hline Surgical Clinic & $3.58 \pm 0.56$ & $4.00 \pm 0.88$ & $3.32 \pm 0.67$ & $3.54 \pm 0.66$ & \\
\hline Emergency Clinic & $3.68 \pm 0.60$ & $4.07 \pm 0.86$ & $3.51 \pm 0.65$ & $3.50 \pm 0.77$ & \\
\hline Intensive Care + Operating Room & $3.89 \pm 0.48$ & $4.25 \pm 0.75$ & $3.70 \pm 0.59$ & $3.81 \pm 0.56$ & \\
\hline Pediatric Clinics & $3.42 \pm 0.46$ & $4.45 \pm 0.46$ & $2.84 \pm 0.89$ & $3.25 \pm 0.71$ & \\
\hline Obstetrics and & $3.58 \pm 0.41$ & $4.22 \pm 0.717$ & $3.17 \pm 0.68$ & $3.54 \pm 0.69$ & \\
\hline Gynecology+Delivery Room & $\mathrm{p}=0.08$ & $\mathrm{p}=0.63$ & $\mathrm{p}=0.02 *$ & $\mathrm{p}=0.43$ & \\
\hline \multicolumn{6}{|l|}{ Educational level } \\
\hline High School & $3.76 \pm 0.53$ & $3.51 \pm 0.64$ & $3.68 \pm 0.73$ & $3.75 \pm 0.53$ & \multirow{5}{*}{$\mathrm{KW}=1.95$} \\
\hline Vocational School & $3.64 \pm 0.48$ & $3.37 \pm 0.68$ & $3.57 \pm 0.69$ & $3.64 \pm 0.48$ & \\
\hline University Graduate & $3.65 \pm 0.57$ & $3.31 \pm 0.71$ & $3.51 \pm 0.73$ & $3.65 \pm 0.57$ & \\
\hline \multirow{2}{*}{ Master's Degree } & $3.57 \pm 0.57$ & $3.41 \pm 0.69$ & $3.45 \pm 0.73$ & $3.57 \pm 0.57$ & \\
\hline & $\mathrm{p}=0.58$ & $\mathrm{p}=0.46$ & $\mathrm{p}=0.49$ & $\mathrm{p}=0.52$ & \\
\hline \multicolumn{6}{|l|}{ Working Time } \\
\hline Less than 5 years & $3.70 \pm 0.52$ & $4.23 \pm 0.77$ & $3.42 \pm 0.67$ & $3.59 \pm 0.65$ & \multirow{4}{*}{$\mathrm{F}=0.44$} \\
\hline $5-9$ year & $3.71 \pm 0.67$ & $4.10 \pm 0.75$ & $3.54 \pm 0.80$ & $3.57 \pm 1.00$ & \\
\hline \multirow[t]{2}{*}{10 years and over } & $3.62 \pm 0.47$ & $4.18 \pm 0.70$ & $3.28 \pm 0.62$ & $3.57 \pm 0.66$ & \\
\hline & $\mathrm{p}=0.64$ & $\mathrm{p}=0.71$ & $\mathrm{p}=0.25$ & $\mathrm{p}=0.98$ & \\
\hline \multicolumn{6}{|l|}{ Did You Experience Disaster? } \\
\hline Yes & $3.64 \pm 0.55$ & $4.17 \pm 0.83$ & $3.34 \pm 0.70$ & $3.54 \pm 0.84$ & \multirow{2}{*}{$\mathrm{t}=-0.001$} \\
\hline No & $\begin{array}{l}3.70 \pm 0.53 \\
0=0.48\end{array}$ & $\begin{array}{l}4.20 \pm 0.71 \\
n=078\end{array}$ & $\begin{array}{c}3.42 \pm 0.71 \\
\mathrm{p}=0.47\end{array}$ & $3.60 \pm 0.71$ & \\
\hline \multicolumn{6}{|l|}{ Participation in Disaster Drills } \\
\hline Participated & $3.74 \pm 0.54$ & $4.18 \pm 0.79$ & $3.46 \pm 0.68$ & $3.71 \pm 0.71$ & \multirow{3}{*}{$\mathrm{t}=1.53$} \\
\hline \multirow[t]{2}{*}{ Not participated } & $3.61 \pm 0.52$ & $4.21 \pm 0.69$ & $3.32 \pm 0.68$ & $3.42 \pm 0.69$ & \\
\hline & $\mathrm{p}=0.12$ & $\mathrm{p}=0.76$ & $\mathrm{p}=0.18$ & $\mathrm{p}=0.008 * *$ & \\
\hline
\end{tabular}

It was found that those who had the highest perception in the disaster response phase were the nurses working in the intensive care + operating room, and those who had the lowest perception were 
nurses working in pediatric clinics. Besides, the mean scores of the nurses participating in the disaster drill were found to be higher than the scores of those who did not participate in the disaster drill $(\mathrm{t}=1.53$; $\mathrm{p}<0.01)$ (Table 4).

\section{Discussion}

Disaster preparedness requires all risk analyses and multidisciplinary management strategies [22]. While all these plans are being made, health workers, especially nurses, who have a great place in the health community, should be actively involved in this planning and be prepared for disasters. The findings of this study, which was conducted to determine the preparedness of nurses against disasters and to measure perceptions of preparedness before, during and after disasters, were discussed in the relevant literature with the findings of the study conducted to determine the readiness of health workers or nurses against disasters.

Disasters are an emergency that occurs at an unexpected time. It was found that $32.2 \%$ of the nurses participating in the study had experienced a disaster before. In the study conducted by Inal et al. it was determined that $18.8 \%$ of the students experienced a disaster [23]. In the study conducted by Şen and Ersoy, it was determined that $18.6 \%$ of the hospital disaster team experienced a disaster [24]. There is a similarity between the results of our research and the results of the studies.

Individuals with disaster training and drill experience work more effectively and efficiently at the time of a disaster. It was determined that $67.3 \%$ of the nurses participating in the study received training on disasters and $55.6 \%$ participated in disaster drills. In the study conducted by Özpulat and Kabasakal, it was determined that $67.8 \%$ of the student nurses received disaster training [25]. In the study conducted by $\mathrm{Al} \mathrm{Khalaileh} \mathrm{et} \mathrm{al.;} 61 \%$ of the nurses received disaster training and 53\% participated in the drills related to disasters [26]. There are similarities between the results of our research and the results of this study. It is thought that the addition of applied disaster education to the nursing curriculum or performing in-service training in hospitals will make nurses feel more experienced and ready.

It is very important that health workers working in hospitals intervene, give care for the wounded during and after the disaster. Therefore, planning should be made before disasters occur. It was found that $68.4 \%$ of the nurses included in the study were aware of the disaster plan of the hospital they work and more than half of those who were informed read this plan. In the study conducted by Vatan and Salur, it was determined that $83.4 \%$ of the executive nurses were aware of the disaster plan of the hospital where they worked [27]. In the study conducted by Çakmak et al., it was determined that $76.1 \%$ of 112 Emergency Aid personnel were aware of the disaster plan of the institution they work [28]. In the study conducted by Fung et al., it was determined that $61 \%$ of the nurses read the hospital disaster plan [29]. There is a similarity between the results of these studies and the results of our research.

Nurses need to know their role to fully fulfill their duties and responsibilities in disaster management. In this context, $88.9 \%$ of the nurses included in our study stated that they had roles in the post-disaster period and that these roles were mostly related to caring for the victims. In the study conducted by Şensoy and Nahcivan, $99.5 \%$ of the nurses stated that they believed that the role of nurses was after the disaster [30]. In the study conducted by Taşkıran and Baykal, $95.6 \%$ said that nurses had a role after the disaster [31]. In the study conducted by Basal and Ahmed, 58.5\% of nurses stated that they have a role to provide care services in disasters [32]. It is seen that there is a similarity between the results of our research and the results of these studies.

Although an emergency or disaster that is experienced, encountered, or seen by people is considered a concept of disaster, there is a widely accepted concept of disaster by the United Nations Humanitarian Organization. In this regard, $99.4 \%$ of the nurses included in our study defined the concept of disaster as natural disasters such as earthquakes and landslides. In a study conducted by Taşkıran and Baykal, it was determined that nurses evaluated all types of disasters as very probable or probable and 
especially they see the earthquakes which are seen more and more often very probable [31]. The results of this study and the results of our study are similar. Furthermore, the reason that natural disasters such as earthquakes or landslides are considered as disasters, is thought to be associated with the occurrence of such disasters in our country, especially in the North of Eastern Anatolia and Eastern Black Sea region.

The mean scores of the DPPSN of the nurses included in the study were $3.68 \pm 0.53$ for the total scale score out of 5 points. Besides, $56.7 \%$ of nurses have stated that they were partially prepared for disasters at the Personal Information Form. These results indicate that nurses who participated in the study perceived their preparedness for disasters at a moderate level. In line with our study, some studies in the literature have shown that nurses have a moderate perception of disaster preparedness $[4,7,33,34]$.

In this study, as seen in Table 4, it was examined whether there was a statistically significant difference between some variables and the DPPSN and subscale scores, and there was only a difference between the variables worked clinic and participating disaster drills.

When we look at the findings based on the clinic that they work, it is seen that the perception of all nurses is high during the intervention phase and statistically significant. In a study conducted by $\mathrm{Al}$ Khalaileh et al. and Özcan and Erol, it is determined that the perception of all nurses is high during the intervention phase and statistically significant $[21,26]$. There is a similarity between the results of these studies and the results of our research. In the intervention stage, it was found that the highest level of preparation perception belonged to the nurses working in the intensive care unit + operating room, and the nurses working in pediatric clinics had the lowest perception of preparation. The second place with the highest level of preparedness perception in the intervention phase is in the emergency department. This is an expected result, which means that nurses who have the most experience to intervene in acute situations have high perceptions.

When we look at the preparedness perceptions of the nurses included in the research according to their participation in the disaster drills, the perceptions of the participants who participated in the disaster drills were high (post-disaster stage $3.71 \pm 0.71$ ); whereas those who did not participate in the disaster, drills were low (post-disaster stage $3.42 \pm 0.69$ ). In the literature supporting our research, some studies have shown that the perception of disaster preparedness of health personnel who have gained disaster experience by having training on disasters or participating in drills is high $[7,10,35]$. According to the results we will draw from this, it is seen that taking applied disaster education throughout nursing education and working life increases nurses' perceptions of preparedness against disasters.

\section{Conclusion and Recommendations}

It was concluded that the nurses' perceptions of disaster preparedness were moderate. It has emerged that nurses have more post-disaster roles and the role of caring for the victims is more important. Disaster preparedness perceptions of the nurses participating in disaster drills were higher than those who did not participate in the drills. It is recommended that nurses' perceptions of preparedness against disasters must be kept high by providing adequate and regular training and drills on disaster preparedness. It is also recommended that different studies should be conducted on this issue.

Ethical Declaration: This work was approved by the ethics committee of Erzincan Binali Y1ldirım University (Date: 19/01/2015, Number: 01/09).

Conflict of interest : The authors declare that they have no conflict of interest.

Authors' Contributions: The authors declare that their contribution to the work is equal.

The compliance to the Research and Publication Ethics: This study was carried out in accordance with the rules of research and publication ethics. 


\section{References}

[1] Kulig, J.C., Penz, K., Karunanayake, C., MacLeod, ML., Jahner, S., Andrews, ME., "Experiences of rural and remote nurses assisting with disaster”, Australas Emerg Nurs J, 20, 98-106, 2017.

[2] Ersoy, Ş., Koçak, A., "Disasters and earthquake preparedness of children and schools in İstanbul, Turkey", Geomatics, Natural Hazards and Risk, 7, 1307-1336, 2016.

[3] Kemaloğlu, M., “Türkiye' de afet yönetiminin tarihi ve yasal gelişimi”, Akademik Bakış Dergisi, 52, 126-147, 2015.

[4] Sangkala, MS., Gerdtz, MF., "Disaster preparedness and learning needs among community health nurse coordinators in South Sulawesi Indonesia", Australasian Emergency Care, 21, 23-30, 2018.

[5] Şahin, N., “Afet Yönetimi ve Acil Yardım Planları”, TMMOB İzmir Kent Sempozyumu, İzmir, Türkiye, 2009, pp. 131-142.

[6] Ejeta, LT., Ardalan, A., Paton, D., "Application of behavioral theories to disaster and emergency health preparedness: A systematic review”, PLOS Currents Disasters, 7, 1-31, 2015.

[7] Rizqillah, AF., Suna, J., "Indonesian emergency nurses' preparedness to respond to disaster: A descriptive survey”, Australasian Emergency Care, 21, 64-68, 2018.

[8] Al Thobaity, A., Plummer, V., Innes, K., Copnell, B., "Perceptions of knowledge of disaster management among military and civilian nurses in Saudi Arabia", Australas Emerg Nurs J, 18, 156-164, 2015.

[9] Olivia, F.W.M., Claudia, L.K.Y., Yuen, L.A., "Nurses' perception of disaster: implications for disaster nursing curriculum", Journal of Clinical Nursing, 18, 3165-3171, 2009.

[10] Ahayalimudin, N., Osman, N.N.S., "Disaster management: Emergency nursing and medical personnel's knowledge, attitude and practices of the East Coast region hospitals of Malaysia", Australas Emerg Nurs J, 19, 203-209, 2016.

[11] Wilkinson, A.M., Matzo, M., "Nursing education for disaster preparedness and response", The Journal of Continuing in Nursing, 46, 65-73, 2015.

[12] Veenema, T.G., "Global disaster nurse preparedness: Moving from reserve torapid action", Health Emergency and Disaster Nursing, 3, 42-47, 2016.

[13] Georgino, M.M., Kress, T., Alexander, S., Beach, M., "Emergency preparedness education for nurses", Journal of Trauma Nursing, 22(5), 240-248, 2015.

[14] Spain, K.M., Clements, P.T., DeRanieri, J.T., Holt, K., "When disaster happens: emergency preparedness for nurse practitioners", The Journal for Nurse Practitioners, 8(1), 38-44, 2012.

[15] Taşkıran, G., Baykal, Ü., “Afetler ve Türkiye'de hemşirelerin afetlere hazır olma durumları: literatür inceleme”, Sağllk ve Hemşirelik Yönetimi Dergisi, 2(4), 79-88, 2017.

[16] Hisar, K.M., Yurdakul, A., "Bir üniversitenin hemşirelik öğrencilerinin afetlerde sağlık hizmetleri ile ilgili bilgilerinin değerlendirilmesi”, MAKÜ Sag. Bil. Enst. Derg, 3(2), 54-65, 2015.

[17] Zarea, K., Beiranvand, S., Sheini-Jaberi, P., Nikbakht-Nasrabadi, A., "Disaster nursing in Iran: challenges and opportunities", Australas Emerg Nurs J, 17, 190-196, 2014.

[18] Demirbaş, H., Sezer, A., Ergun, A., “Afet yönetiminde halk sağlığı hemşiresinin rol ve sorumlulukları”, F.N. Hem. Derg, 21(2), 122-128, 2013. 
[19] Ranse, J., Hutton, A., Wilson, R., Usher, K., "Leadership opportunities for mental health nurses in the field of disaster preparation, response, and recovery", Issues in Mental Healty Nursing, 36(5), 391-394, 2015.

[20] Cullen, B., "Roles for the WOC nurse in a disaster", $J$ Wound Ostomy Continence Nurs, 35, 282286, 2008.

[21] Özcan, F., Erol, S., "Hemşirelerin Afete Hazır Olma Durumu ve Hazırlık Algısı: Bir Ölçek Geliştirme Çalışması”, 18. Ulusal Halk Sağlı̆̆l Kongresi, Konya, Türkiye, 2015, pp. 734-735.

[22] Nash, T.J., "A guide to emergency preparedness and disaster nursing education resources", Healthy Emergency and Disaster Nursing, 4, 12-25, 2017.

[23] İnal, E., Kocagöz, S., Turan, M., “Temel afet bilinç ve hazırlık düzeyinin saptanmasına yönelik bir araştırma”, Türkiye Acil Tıp Dergisi, 12(1), 15-19, 2012.

[24] Şen, G., Ersoy, G., "Hastane afet ekibinin afete hazırlık konusundaki bilgi düzeylerinin değerlendirilmesi”, Gümüşhane Üniversitesi Sağllk Bilimleri Dergisi, 6(4), 122-130, 2017.

[25] Özpulat, F., Kabasakal, E., "Knowledge levels of nursing students on disaster nursing and their state of disaster preparedness", Int J Med Res Health Sci, 7(8), 165-174, 2018.

[26] Al Khalaileh, M.A., Bond, E., Alasad, J.A., “Jordanian nurses' perceptions of their preparedness for disaster management”, International Emergency Nursing, 20, 14-23, 2012.

[27] Vatan, F., Salur, D., "Yönetici hemşirelerin hastanelerdeki deprem afet planları konusundaki görüşlerinin incelenmesi”, Maltepe Üniversite Hemşirelik Bilim ve Sanatı Dergisi, 3(1), 32-44, 2010.

[28] Çakmak, H., Er, R.A., Öz, Y.C., Aker, A.T., "Kocaeli 112 acil yardım birimlerinde çalışan personelin Marmara depreminden etkilenme ve olası afetlere hazırlık durumlarının saptanması", Akademik Acil Tip Dergisi, 2, 83-88, 2010.

[29] Fung, O.W.M., Loke, A.Y., Lai, C.K.Y., "Disaster preparednes among Hong kong nurses", Journal of Advanced Nursing, 62, 698-703, 2008.

[30] Şensoy, F.Ç., Nahcivan, N., “Türk Kızılay'ında Çalışan Hemşirelerin Afetlere Hazırlık Durumları”, 15. Ulusal Halk Sağlığı Kongresi, Bursa, Türkiye, 2012, pp. 207-209.

[31] Taşkıran, G., Baykal, Ü., "Hemşirelerin afetlere ilişkin görüşleri deneyimleri ve hazırlık algısı", Uluslararası Hakemli Hemşirelik Araştırmaları Dergisi, 10, 36-58, 2017.

[32] Basal, A.A., Ahmed, R.E., "Perception of nurses' regarding role, preparedness and management skills during hospital disasters", International Journal of Novel Research in Healthcare and Nursing, 5, 151-161, 2018.

[33] Al-Ali, N.M., Abu Ibaid, A.H., "Health-care providers' perception of knowledge, skills and preparedness for disaster management in primary health-care centres in Jordan", EMHJ, 21, 713$721,2015$.

[34] Tiara., Thongkrajai, E., "Nurses Preparedness for Disaster Management in Lampung Province, Indonesia", Asian Academic Society International Conference Proceeding Series, Thailand, 2017, pp. 65-71.

[35] Baack, S., Alfred, D., "Nurses' preparedness and perceived competence in managing disasters", Journal of Nursing Scholarship, 45, 281-287, 2013. 